\title{
ANALISIS PEMASARAN KOPRA DI DESA CINYASAG KECAMATAN PANAWANGAN KABUPATEN CIAMIS
}

\author{
ANALYSIS OF KOPRA MARKETING IN CINYASAG VILLAGE \\ KECAMATAN PANAWANGAN CIAMIS DISTRICT
}

\author{
BENI GUNAWAN ${ }^{1}$, TRISNA INSAN NOOR ${ }^{2}$, BUDI SETIA ${ }^{1}$ \\ ${ }^{1}$ Mahasiswa Fakultas Pertanian Universitas Galuh Ciamis \\ ${ }^{2}$ Dosen Fakultas Pertanian Universitas Padjadjaran \\ *E-mail : benigunawan98@gmail.com)
}

\begin{abstract}
ABSTRAK
Penelitian ini bertujuan untuk mengetahui: 1) Saluran pemasaran kopra di Desa Cinyasag Kecamatan Panawangan Kabupaten Ciamis, 2) Besarnya biaya, marjin dan keuntungan pemasaran kopra di Desa Cinyasag Kecamatan Panawangan Kabupaten Ciamis, 3) Besarnya perolehan yang diterima produsen kopra di Desa Cinyasag Kecamatan Panawangan Kabupeten Ciamis. Penelitian ini dilaksanakan di Desa Cinyasag Kecamatan Panawangan Kabupaten Ciamis. Pemasaran kopra di Desa Cinyasag. Hasil penelitian menunjukkan bahwa: 1) Terdapat satu saluran pemasaran kopra dari perajin sampai ke tangan konsumen akhir yaitu dari Pengrajin - Pedagang Pengumpul - Pedagang Besar - Konsumen Akhir, 2) Saluran pemasaran kopra melibatkan dua lembaga pemasaran yaitu pedagang pengumpul dan pedagang pengecer. Besarnya total marjin pemasaran pada saluran wilayah pasar Manis Ciamis Rp 4.500,- per kilogram dengan total biaya pemasaran sebesar Rp 476,- per kilogram sehingga total keuntungan pemasaran sebesar Rp 3.024,-- per kilogram. Sedangkan pada saluran pasar Kawali, besarnya total marjin pemasaran adalah Rp.4.000,00 per kilogram dengan total biaya pemasaran sebesar Rp. 464,- per kilogram sehingga total keuntungan pemasaran sebesar Rp. 4.536,- per kilogram. Dari kedua saluran pemasaran tersebut, saluran pemasaran Pasar Kawali mempunyai keuntungan terbesar dengan biaya terkecil, 3) Besarnya bagian harga yang diterima perajin (produsen share) pada saluran wilayah pasar Manis Ciamis adalah sebesar 69 persen, sedangkan pada saluran pasar Kawali adalah 75 persen. Dari saluran pemasaran tersebut dapat diketahui bahwa nilai Produsen Share terbesar yaitu saluran pemasaran Pasar Kawali, dikarenakan saluran pemasaran pasar Kawali memiliki marjin terkecil dibandingkan saluran pemasaran pasar Manis Ciamis.
\end{abstract}

\section{Kata Kunci : Pemasaran, Kopra, Produsen Share}

\begin{abstract}
This study aims to determine: 1) The copra marketing channel in Cinyasag Village, Panawangan District, Ciamis Regency, 2) The amount of costs, margins and profits of copra marketing in Cinyasag Village, Panawangan District, Ciamis Regency, 3) The amount of revenue received by copra producers in Cinyasag Village, Panawangan District Ciamis Regency. This research was conducted in Cinyasag Village, Panawangan District, Ciamis Regency. Copra marketing in Cinyasag Village. The results showed that: 1) There was one marketing channel for copra from craftsmen to end consumers, namely from craftsmen - collectors - wholesalers - final consumers, 2) The copra marketing channel involved two marketing agencies, namely collectors and retailers. The total marketing margin in the Manis Ciamis market area channel is IDR 4,500 per kilogram with a total marketing cost of IDR 476 per kilogram, so that the total marketing profit is IDR 3,024 per kilogram. Meanwhile, in the Kawali market channel, the total marketing margin is Rp. 4,000 per kilogram with a total marketing cost of $R p .464$, - per kilogram so that the total marketing profit is Rp. 4,536, - per kilogram. Of the two marketing channels, the Kawali Market marketing channel has the largest advantage with the smallest cost, 3) The share of the price received by craftsmen (producer shares) in the Manis Ciamis market area channel is 69 percent, while in the Kawali market channel it is 75 percent. From the marketing channel, it can be seen that the largest Producer Share value is the Kawali Market marketing channel,
\end{abstract}


because the Kawali market marketing channel has the smallest margin compared to the Manis Ciamis market marketing channel.

Keywords: Marketing, Copra, Producer Share

\section{PENDAHULUAN}

Pembangunan sektor pertanian merupakan hal yang sangat penting, karena Indonesia merupakan negara agraris yang melakukan kegiatannya di sektor pertanian. Indonesia yang merupakan negara dengan basis perekonomian agraris, tidak mungkin melepaskan pembangunan pertanian dalam seluruh kebijakan pembangunan nasional, bahkan merupakan suatu kewajiban menjadikan pembangunan pertanian sebagai prioritas (Indriyani, 2019).

Indonesia merupakan produsen kelapa terbesar di dunia dengan luas tanaman kelapa sekitar 3,8 juta ha dan produksi sekitar 16,498 miliar butir kelapa (3,3 juta ton setara kopra) (Pohan, 2016). Kopra merupakan buah kelapa bagian dalam yang segar yang dapat dikeringkan dengan metode konvensional menggunakan sinar matahari (sun drying), pengasapan atau mengeringkan di atas api terbuka, pengeringan dengan pemanasan secara tidak langsung (indirect drying) 1 pengeringan dengan udara vakum (vacuum drying).

Kabupaten Ciamis merupakan salah satu pengekspor kopra hingga ke luar negeri karena kopra yang dihasilkan memiliki kualitas yang sangat baik. Pengrajin kopra terbanyak yaitu berada di Kecamatan Panawangan.

Berdasarkan data Dinas Pertanian Kabupaten Ciamis, pada tahun 2018 produsen kopra di Kabupaten Ciamis terbanyak ada di Kecamatan Panawangan yaitu dengan jumlah 14 produsen. Jika dibandingkan antara produsen kopra di Kecamatan Panawangan dengan Kecamatan lain di Kabupaten Ciamis, bahwa menurut supplier kopra hanya kopra dari kecamatan Panawangan lah yang bisa mengekspor hingga ke luar negeri. Dan dari 14 produsen kopra di Kecamatan Panawangan yang paling tinggi tingkat produksinya ada di Desa Cinyasag, dari itu peneliti tertarik untuk melakukan penelitian di produsen kopra Desa Cinyasag. Pembuatan kopra yang dilakukan oleh petani di Desa Cinyasag Kecamatan Panawangan Kabupaten Ciamis dengan menggunakan bahan baku dari daging kelapa yang berasal dari tanaman kelapa yang dibudidayakan oleh para petani di Desa Cinyasag Kecamatan Panawangan Kabupaten Ciamis. 


\section{METODE PENELITIAN}

Jenis penelitian yang digunakan adalah metode survey dengan pendekatan kuantitatif. Menurut (Fraenkel dan Wallen (1993) dalam Arifin, 2011: 64) menyebutkan bahwa penelitian survei adalah penelitian dengan mengumpulkan informasi dari suatu sampel dengan menanyakannya melalui angket atau wawancara untuk menggambarkan berbagai aspek dari populasi'.

Adapun Sampel yang diambil dalam penelitian ini adalah 14 orang. Yang terdiri dari 8 orang pengrajin kopra, 2 orang pedagang pengumpul, dan 4 orang pedagang besar. Teknik pengambilan sampel menggunakan total sampling. Total Sampling adalah teknik pengambilan sampel dimana jumlah sampel sama dengan populasi (Sugiyono, 2014).

Untuk mengetahui saluran pemasaran kopra digunakan analisis deskriptif kualitatif:

1. Untuk mengetahui besarnya marjin pemasaran menggunakan rumus (Angipora, 2002) :

$\mathrm{Mm}=\mathrm{He}-\mathrm{Hp}$

Keterangan:

$$
\begin{aligned}
\mathrm{Mm}= & \text { Marjin pemasaran } \\
\mathrm{He}= & \text { Harga eceran di tingkat } \\
& \text { lembaga pemasaran } \\
& (\mathrm{Rp} / \mathrm{kg})
\end{aligned}
$$

$\mathrm{Hp}=$ Harga produk di tingkat perajin $(\mathrm{Rp} / \mathrm{kg})$

Karena dalam marjin pemasaran terdapat dua komponen yaitu komponen biaya dan komponen keuntungan maka :

$\mathbf{M m}=\pi+\mathbf{T C}$

Keterangan:

$\mathrm{Mm}=$ Marjin pemasaran

$\pi=$ Keuntungan di tingkat lembaga pemasaran

$\mathrm{TC}=$ Total biaya pemasaran di tingkat lembaga pemasaran

2. Untuk mengetahui bagian harga yang diterima perajin (share) menggunakan rumus (Angipora, 2002) :

$P S=\frac{\mathrm{Hp}}{\mathrm{He}} \times 100 \%$

Keterangan :

$P S=$ Bagian harga yang diterimaprodusen (Produce'r share)

$\mathrm{Hp}=$ Harga di tingkat perajin $(\mathrm{Rp} / \mathrm{kg})$

$\mathrm{He}=$ Harga di tingkat lembaga pemasaran $(\mathrm{Rp} / \mathrm{kg})$

\section{HASIL DAN PEMBAHASAN}

1. Saluran Pemasaran Kopra

a. Kegiatan Pemasaran di Tingkat Perajin 
Skala usaha perajin kopra di Desa Cinyasag Kecamatan Panawangan Kabupaten Ciamis beraneka ragam, baik dalam jumlah pohon yang dimiliki maupun jumlah produksi yang dihasilkan. Penjualan kopra bervariasi dari 23 kilogram sampai 45 kilogram dengan ratarata 40 kilogram. Dari kegiatan produksi kopra yang dihasilkan selanjutnya dikemas dengan menggunakan plastik, sebelum pedagang pengumpul datang untuk mengambilnya. Harga jual kopra di tingkat perajin sebesar $\mathrm{Rp}$ 5.500,- per kilogram dengan sistem pembayaran tunai.

Hasil penelitian menunjukan bahwa jumlah produksi kopra sebanyak 239 kilogram setiap minggunya. Untuk lebih jelasnya perhitungan rincian volume jual, dan harga jual gula kopra di tingkat perajin dapat dilihat pada lampiran 6.

\section{b. Kegiatan di Tingkat Pengumpul}

Hasil penelitian menunjukan bahwa pedagang pengumpul membeli kopra dari perajin dengan jumlah volume beli sebanyak 239 kilogram. Sebanyak 152 kilogram untuk dipasarkan kewilayah pasar Manis Ciamis, dan 87 Kilogram untuk wilayah pasar Kawali. Pada pasar Manis Ciamis jumlah volume jual sebanyak 287,50 kilogram dan jumlah volume susut 2 kilogram. Jumlah volume susut ditanggung sepenuhnya oleh pedagang pengumpul. Dengan harga beli ke perajin adalah Rp 5.500,- per kilogram dan harga jual ke pedagang besar yang berada diwilayah pasar Kawali yaitu Rp 7.000,- perkilogram, sedangkan pada wilayah pasar Manis Ciamis jumlah volume jual sebanyak 152 kilogram dan jumlah volume susut 4 kilogram. Jumlah volume susut ditanggung sepenuhnya oleh pedagang pengumpul. Harga beli ke perajin adalah Rp 5.500,- perkilogram dan harga jual ke pedagang besar di wilayah Pasar Kawali sebesar Rp 7.500,perkilogram. Untuk lebih jelasnya perhitungan rincian volume beli, volume jual, volume susut, harga beli dan harga jual kopra di pedagang pengumpul dapat dilihat pada Lampiran 7.

Perlakuan yang dilakukan oleh pedagang pengumpul yaitu mengambil kopra ke tingkat perajin dan mengangkut kopra dari perajin dan disimpan terlebih dahulu sampai volume kopra terkumpul banyak sebelum lanjut ke pedagang besar, selanjutnya bongkar muat dan pengemasan. Proses perlakuan tersebut berkaitan dengan besarnya biaya yang dikeluarkan oleh pedagang pengumpul, untuk lebih jelas perhitungan rincian biaya pemasaran di pedagang pengumpul dapat dilihat pada lampiran 8. Untuk jenis dan 
besarnya rata-rata biaya dapat dilihat pada Gambar 10 .

\begin{tabular}{|c|c|c|}
\hline $\begin{array}{r}100 \% \\
50 \% \\
0 \%\end{array}$ & & \\
\hline & Saluran Pasar Kawali & $\begin{array}{c}\text { Saluran Pasar Manis } \\
\text { Ciamis }\end{array}$ \\
\hline Pengemasan & $14,99 \%$ & $16,98 \%$ \\
\hline Bongkar muat & $4,08 \%$ & $6,17 \%$ \\
\hline Pengangkutan & $46,33 \%$ & $54,01 \%$ \\
\hline Penyimpanan & $4,08 \%$ & $4,63 \%$ \\
\hline Penyusutan & $30,52 \%$ & $18,21 \%$ \\
\hline
\end{tabular}

\section{Gambar 10. Rata-rata Biaya Pemasaran Gula Aren di Tingkat Pedagang Pengumpul}

Gambar 10 menunjukan bahwa besarnya biaya pemasaran kopra di pedagang pengumpul sebesar $\mathrm{Rp} 253$,untuk wilayah pasar Kawali dengan jenis yang paling besar adalah biaya pengangkutan (46,33 Persen) dikarenakan jarak tempuh saat pengiriman kopra. Sedangkan besarnya biaya pemasaran kopra di pedagang pengumpul wilayah pasar Ciamis Manis adalah sebesar Rp 241,- dengan jenis biaya yang paling besar adalah biaya pengangkutan $(54,01$ persen) dikarenakan jarak yang ditempuh saat pengiriman kopra.

\section{c. Kegiatan di Tingkat Pedagang Besar}

Hasil penelitian menunjukan bahwa perajin kopra menjual ke pedagang pengumpul lalu pedagang pengumpul menjual ke pedagang besar di wilayah pasar Kawali dan di wilayah pasar Ciamis Manis. Perlakuan yang dilakukan oleh pedagang besar sama seperti pedagang pengumpul. Pedagang besar mengambil kopra dari pedagang pengumpul, setelah itu melakukan bongkar muat dan pengemasan kembali jika ada yang rusak, dalam proses pengangkutan biasanya terjadi perubahan warna kopra menjadi kuning ataupun menjadi tidak bulat sempurna, proses tersebut sering disebut penyusutan, setelah itu sebelum dijual ke konsumen, pedagang besar melakukan proses penyimpanan supaya fisik kopra tidak berubah. Proses perlakuan tersebut berkaitan dengan besarnya biaya yang dikeluarkan oleh pedagang besar. Untuk lebih jelasnya perhitungan rincian biaya pemasaran di pedagang besar dapat dilihat pada Lampiran 10. Untuk jenis dan 
besarnya rata-rata biaya dapat dilihat pada Gambar 11.

\begin{tabular}{|c|c|}
\hline \multicolumn{1}{|c|}{} \\
\hline
\end{tabular}

\section{Gambar 11. Rata-rata Biaya Pemasaran kopra di Tingkat Pedagang Besar}

Gambar 11 menunjukan bahwa besarnya biaya pemasaran kopra di pedagang besar sebesar Rp 223,- untuk wilayah pasar Kawali dengan jenis yang paling besar adalah biaya pengemasan yaitu sebesar (39,53 Persen) dan besarnya biaya pemasaran kopra di pedagang besar wilayah pasar Manis Ciamis adalah sebesar Rp 223,- dengan jenis biaya yang paling besar adalah biaya pengemasan yaitu sebesar (40,32 persen) dikarenakan konsumen sering kali meminta kemasan yang berbeda pada saat jual beli.

\section{Analisis Biaya, Marjin, dan Keuntungan Pemasaran antar Lembaga Pemasaran}

Perlakuan-perlakuan yang dilakukan oleh lembaga pemasaran dapat mempengaruhi besarnya biaya yang harus dikeluarkan oleh setiap lembaga pemasaran serta berpengaruh pula terhadap besarnya marjin dan keuntungan pemasaran (Soekartawi, 2000).

Perlakuan-perlakuan yang dilakukan oleh lembaga pemasaran dapat mempengaruhi besarnya biaya yang harus dikeluarkan oleh setiap lembaga pemasaran serta berpengaruh pula terhadap besarnya marjin dan keuntungan pemasaran (Soekartawi, 2000).

Besarnya biaya yang dikeluarkan oleh perajin akan berpengaruh terhadap harga produk dan akan mempengaruhi 
besar kecilnya nilai share. Besarnya biaya, marjin dan keuntungan pemasaran dapat dilihat pada Tabel 2 .

Tabel 2. Rata-rata Biaya, Marjin, dan Keuntungan Pemasaran Kopra.

\begin{tabular}{|l|l|r|r|}
\hline No & \multicolumn{1}{|c|}{$\begin{array}{c}\text { Sembaga } \\
\text { Pemasaran } \\
\text { Pemasaran } \\
\text { (Pasar } \\
\text { Manis } \\
\text { Ciamis) } \\
\text { (Rp/Kg) }\end{array}$} & $\begin{array}{c}\text { Saluran } \\
\text { Pemasaran } \\
\text { (Pasar } \\
\text { Kawali) } \\
\text { Rp/Kg) }\end{array}$ \\
\hline 1 & Perajin & \multicolumn{1}{|c|}{} \\
\hline & Harga Jual & $5.500,-$ & $5.500,-$ \\
\hline 2 & Pedagang Pengumpul \\
\hline & Harga Beli & $5.500,-$ & $5.500,-$ \\
\hline & Harga Jual & $7.000,-$ & $7.500,-$ \\
\hline & Marjin & $1.500,-$ & $2.000,-$ \\
\hline & Biaya & $253,-$ & $241,-$ \\
\hline & Keuntungan & $1.247,-$ & $1,759-$ \\
\hline 3 & Pedagang Besar & \\
\hline & Harga Beli & $6.500,-$ & $6.500,-$ \\
\hline & Harga Jual & $9.500,-$ & $8.000,-$ \\
\hline & Marjin & $3.000,-$ & $2.000,-$ \\
\hline & Biaya & $223,-$ & $223,-$ \\
\hline & Keuntungan & $1.777,-$ & $2.777-$ \\
\hline 4 & Total & \multicolumn{2}{|c|}{} \\
\hline & Marjin & $4.500,-$ & $4.000,-$ \\
\hline & Biaya & $476,-$ & $464,-$ \\
\hline & Keuntungan & $3.024,-$ & $4.536,-$ \\
\hline
\end{tabular}

Tabel 2 menunjukan bahwa saluran pemasaran Pasar Manis Ciamis mempunyai total marjin sebesar $\operatorname{Rp} 4.500$,per kilogram dengan total biaya pemasaran sebesar Rp 476,- per kilogram sehingga keuntungan sebesar $\mathrm{Rp} 3.024,-$ per kilogram, sedangkan saluran pemasaran Kawali mempunyai total marjin sebesar Rp 4.000,- perkilogram dengan total biaya sebesar Rp 464,- per kilogram sehingga keuntungan sebesar $\mathrm{Rp}$ 4.536,- per kilogram. Dari kedua saluran pemasaran tersebut, saluran pemasaran Pasar Kawali mempunyai total keuntungan terbesar dengan total biaya terkecil. Hal ini disebabkan karena biaya yang paling besar pada pedagang pengumpul pada saluran pemasaran Pasar Manis Ciamis yang didominasi oleh penyusutan jauh lebih besar dari pedagang pengumpul Pasar Kawali. Pada saluran pemasaran Pasar Manis Ciamis transportasi yang digunakan yaitu sepeda motor dikarenakan volume penjualan sedikit, sedangkan saluran pemasaran Pasar Ciamis menggunakan transportasi mobil, sehingga penyusutan lebih besar yang menggunakan transportasi motor. Kemudian keuntungan lembaga pemasaran yang paling besar adalah pedagang besar. Pedagang besar mengambil keuntungan paling besar disebabkan resiko penjualan diantaranya barang rusak atau barang sisa penjualan yang tidak terjual harus di olah dan dikemas kembali.

\section{Produce'r Share atau Persentase}

\section{Bagian Harga yang Diterima Perajin}

Produce'r Share adalah perbadingan harga yang diterima perajin dengan harga yang dibayarkan konsumen akhir kemudian dikali seratus persen. Untung dan ruginya para perajin tidak ditentukan oleh besarnya dan kecilnya nilai Produce'r Share tetapi dipengaruhi oleh harga produk 
dan biaya produksi yang dikeluarkan (Angipora, 2002).

Berdasarkan hasil penelitian menunjukan bahwa harga jual kopra di perajin pada saluran wilayah pasar Manis
Ciamis sebesar Rp.5.500,00 per kilogram, dipedagang pengumpul sebesar Rp 6.000,dan dipedagang besar sebesar Rp.8.000,00 per kilogram, maka besarnya nilai Produce'r Share adalah :

\begin{tabular}{|c|}
\hline Perajin \\
$21,21 \%$ \\
$12,12 \%$ \\
$66,67 \%$ \\
Produsen Share \\
\hline
\end{tabular}

\section{Gambar 12. Produsen Share Saluran 1 Pasar Manis Ciamis}

Gambar 12 menunjukan bahwa nilai Produce'r Share Saluran pemasaran wilayah pasar Manis Ciamis adalah 69 persen, artinya besarnya bagian harga yang diterima produsen yaitu 69 persen dari harga yang dibayarkan kosumen.
Kemudian Harga jual kopra di perajin pada saluran pemasaran wilayah pasar Kawali sebesar Rp.5.500,00 per kilogram, dipedagang pengumpul sebesar Rp 7.000,- dan dipedagang besar sebesar Rp 8.000,- per kilogram, maka besarnya nilai Produce'r Share pada saluran satu wilayah pasar Kawali adalah :

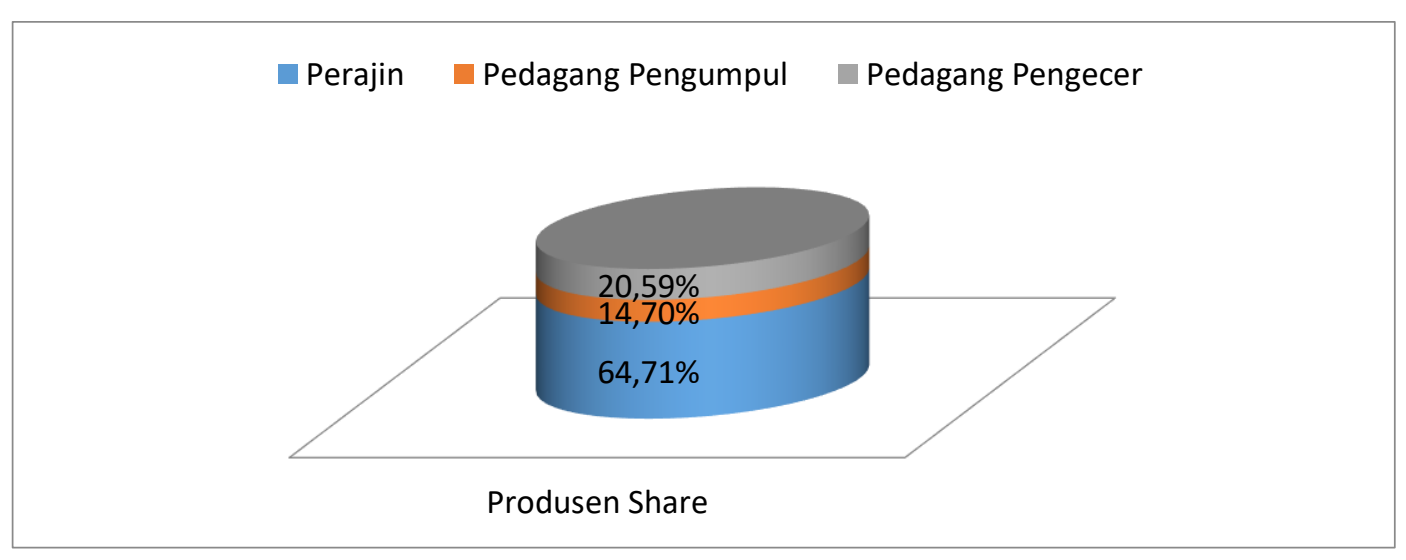

Gambar 13. Produsen Share Saluran Pasar Kawali 
Gambar 13 menunjukan bahwa nilai Produce'r Share saluran pemasaran wilayah pasar Kawali adalah 75 persen, artinya besarnya bagian harga yang diterima produsen yaitu 75 persen dari harga yang dibayarkan kosumen.

Dari saluran pemasaran tersebut dapat diketahui bahwa nilai Produce'r Share terbesar yaitu saluran pemasaran Pasar Kawali, dikarenakan saluran pemasaran Pasar Kawali memiliki harga jual di tingkat besar yang kecil dibandingkan saluran pemasaran Pasar Manis Ciamis.

\section{KESIMPULAN DAN SARAN}

\section{Kesimpulan}

Berdasarkan hasil dan pembahasan, maka dapat ditarik beberapa kesimpulan sebagai berikut :

1. Terdapat satu saluran pemasaran kopra dari perajin sampai ke tangan konsumen akhir yaitu dari Pengrajin - Pedagang Pengumpul - Pedagang Besar Konsumen Akhir.

2. Saluran pemasaran kopra melibatkan dua lembaga pemasaran yaitu pedagang pengumpul dan pedagang besar. Besarnya total marjin pemasaran pada saluran wilayah pasar Manis Ciamis Rp 4.500,- per kilogram dengan total biaya pemasaran sebesar Rp 476,- per kilogram sehingga total keuntungan pemasaran sebesar $\mathrm{Rp} \mathrm{3.024,-}$ per kilogram. Sedangkan pada saluran pasar Kawali, besarnya total marjin pemasaran adalah Rp.4.000,00 per kilogram dengan total biaya pemasaran sebesar Rp. 464,- per kilogram sehingga total keuntungan pemasaran sebesar Rp. 4.536,- per kilogram. Dari kedua saluran pemasaran tersebut, saluran pemasaran Pasar Kawali mempunyai keuntungan terbesar dengan biaya terkecil.

3. Besarnya bagian harga yang diterima perajin (produsen share) pada saluran wilayah pasar Manis Ciamis adalah sebesar 69 persen, sedangkan pada saluran pasar Kawali adalah 75 persen. Dari saluran pemasaran tersebut dapat diketahui bahwa nilai Produsen Share terbesar yaitu saluran pemasaran Pasar Kawali, dikarenakan saluran pemasaran pasar Kawali memiliki marjin terkecil dibandingkan saluran pemasaran pasar Manis Ciamis.

\section{Saran}

Berdasarkan kesimpulan, maka saran yang dapat disampaikan adalah perajin kopra harus lebih aktif mencari peluang pasar dengan cara menjalin kemitraan dengan berbagai lembaga pemasaran sehingga dapat dipilih saluran 
pemasaran yang lebih menguntungkan.

Kemudian dalam hal modal bisa meminjam ke perbankkan.

\section{DAFTAR PUSTAKA}

Amin, Samsul Munir, 2009, Ilmu Dakwah, Jakarta, Amzah.

Angipora, Marius, P. 2002. Dasar-Dasar Pemasaran. PT.Raja Grafindo Persada. Jakarta

Anisa. 2013. Prosedur Penelitian Suatu Pendekatan Praktek. Jakarta. Rineka Cipta

Arikunto, S. 2006. Metode Penelitian Kualitatif. Jakarta. Bumi Aksara.

Basu Swastha. 2003. Manajemen Pemasaran Modern. (Edisi kedua). Cetakan ke sebelas. Yogyakarta. Liberty Offset.

Basu Swastha dan Irawan. 2005. Asas-asas Marketing. Liberty. Yogyakarta.

Christian, Laras. dan Prakoso, Adi. 2009.Pembuatan Minyak Kelapa Murni (VCO) Dengan Metode Fermentasi Dengan Ragi Tempe, Laporan Hasil Penelitian. Fakultas Teknik Kimia. Universitas Sebelas Maret Surakarta.

[Deptan] Departemen Pertanian, 2009. Petunjuk Teknis Verifikasi Dokumen Pengembangan Usaha Agribisnis Pedesaan (PUAP).Jakarta. Departemen Pertanian.

Fatayat, dkk. 2017. (Cocopreneurship) Aneka Peluang Bisnis dari Kelapa. Lily Publisher. Yogyakarta.

Gilarso, 2001. Pengantar Ilmu Ekonomi. Kanisius. Yogyakarta.
Ginting, Paham. 2006. Filsafat Ilmu dan Metode Penelitian. USU Press. Medan

Hidayat, dkk. 2016. Agribisnis Tanaman Perkebunan. Penebar Swadaya. Jakarta.

Indriyani. 2019. Dasar-dasar Demografi. FE Universitas Indonesia. Jakarta.

Kotler, K. 2009. Manajemen Pemasaran 1. Edisi ketiga belas. Jakarta. Erlangga

Lukman Syamsudin. 2007. Manajemen Keuangan Perusahaan. Jakarta. PT Raja Grafindo Persada.

Minhar, Ikhsan. 2016. Analisis Nilai Tambah Dan Pemasaran Kopra (Kasus: Desa Silo Baru, Kecamatan Silau Laut, Kabupaten Asahan). Jurnal. Hal 122.

Pohan. Indri. Pratiwi. 2016. Analisis dan Nilai Tambah Pemasaran Kopra. Vol 4. Hal 116.

Soekartawi. 2002.Prinsip Dasar Manajemen Pemasaran Hasil-Hasil Pertanian Teori dan Aplikasinya. Raja Grafindo Persada. Jakarta.

Sugiyono. 2014. Metode Penelitian Pendidikan Pendekatan Kuantitatif, Kualitatif, dan $R \& D$. Bandung. Alfabeta.

Suharyani. 2012.Tanaman Kelapa, Budidaya Dan Pemanfaatannya. Penerbit Kanisius. Yogyakarta.

Syafrini E. 2013. Minyak kelapa [Serial Online]. [Skripsi]. Sumatera Utara. Universitas Sumatera Utara.

Wijaya Hengki Prasetio.2006. Analisis Saluran Pemasaran Kopra (Studi Kasus Di Desa Sindangsari 
Jurnal Ilmiah Mahasiswa AGROINFO GALUH

Volume 8, Nomor 2, Mei 2021 : 622-632

Kecamatan Cimerak Kabupaten Pangandaran). Vol 4. Hal. 132.

Yesi, dan Hidayah. 2014. Pembuatan virgin coconut oil (VCO) dengan metode sentrifugasi. Surabaya. Fakultas Teknologi Industri UPN "Veteran" Jatim. Hal. 1-8 